\title{
Effects of protein restriction in utero on the metabolism of mink dams (Neovison vison) and on mink kit survival as well as on postnatal growth
}

\author{
Kristine Vesterdorf, Adrian Harrison, Connie Frank Matthiesen, Anne-Helene Tauson ${ }^{\star}$ \\ Department of Animal and Veterinary Basic Sciences, Faculty of Life Sciences, University of Copenhagen, Copenhagen, Denmark; \\ *Corresponding Author: aht@life.ku.dk
}

Received 30 September 2011; revised 4 November 2011; accepted 15 November 2011

\begin{abstract}
Protein restriction in utero may give rise to restricted growth as well as induce metabolically related diseases. In order to determine the suitability of mink as an animal model for metabolism studies, the effects of protein restriction during gestation on dam and kit performance must first be determined. Mink dams were fed an adequate protein (AP; crude protein:fat:carbohydrate ratio of $31: 55: 14 \%$ of metabolizable energy, ME) or a low protein diet (LP; $19 \%: 49 \%$ : $32 \%$ of ME) during the last $21.2 \pm 3.3$ days of gestation, followed by an adequate diet during lactation. Respiration and balance experiments were performed during late gestation and twice during lactation. The dietary treatment only affected energy metabolism traits significantly during the treatment period in late gestation, such that LP dams oxidized less protein $(12 \%$ vs $23 \%$ of heat production, $\mathrm{HE}, P=0.001$ ) but more carbohydrate ( $37 \%$ vs $26 \%$ of $\mathrm{HE}, P<0.05)$, and retained less nitrogen $\left(0.3 \mathrm{vs} 0.4 \mathbf{~ g} \cdot \mathbf{k g}^{-0.75} \cdot\right.$ day $^{-1}$, $P<0.05)$ than AP dams. Reproductive performance and kit organ growth were not affected by diet. Kit losses up to weaning were higher in LP than AP dams $(2.0$ vs $1.4, P<0.05)$. LP fetuses weighed less ( 8.3 vs $11.6 \mathrm{~g}, P<0.001)$ and were shorter $(6.2$ vs $7.6 \mathrm{~cm}, P<0.001)$ than AP fetuses, however, differences might have been due to different implantation times. LP kits weighed $8.5 \%$ less than AP kits at birth, and remained lighter until 21 days of age. The LP diet caused growth restriction and increased kit mortality indicating that the dietary protein supply during late gestation was suboptimal to requirements. The long-term consequences of protein restriction in utero in terms of permanent metabolic changes in adulthood now need to be investi-
\end{abstract}

gated.

Keywords: Intrauterine Metabolic Programming; Nitrogen Metabolism; Reproduction Performance; Growth Rate; Postnatal Development; Organ

Development

\section{INTRODUCTION}

It is widely recognized that adequate intrauterine and early postnatal nutrient and energy supply is of utmost importance for adult animal performance, health, and life span. Malnutrition in utero may cause metabolic adaptations or "programming", which can be exemplified by "the thrifty phenotype" theory. Conversely, excess postnatal nutrient supply may cause the development of metabolically related diseases in later life [1]. Fetal plasticity allows for adaptations to a compromised nutritional environment in utero by reducing growth and development of the fetus [2]. In humans, such a reduction in birth weight is closely correlated with the development of diseases in adulthood, e.g. Type 2 diabetes [3], heart disease [4], and hypertension [5]. Moreover, the longterm effects of metabolic programming may differ according to the period during gestation in which a nutritional challenge is imposed, as well as whether this challenge occurs at a sensitive time period for fetal organ and endocrine system development [6].

The low or restricted protein (LP) animal model has been extensively used in the study of birth weight [7] and the consequences of intrauterine malnutrition on the development of disease in later life [8]. Altered growth patterns in neonates and young individuals have been linked to adaptive changes in fetal organ development in response to a restricted nutrient environment in utero [9]. As such, protein restriction during gestation in rats, and mink was associated with reduced body weights of the offspring (rat: [10]; mink: [11]). Gestational protein restriction further caused a decrease in liver mass in rats 
[10]. Most LP animal model studies have been performed with mice, rats, and sheep, but in this experiment we have chosen the mink, a strict carnivore, as an alternative animal model.

The mink has stringent seasonal cycles of varied food intake, demonstrating a seasonal propensity to accrete large amounts of body fat resulting in obese animals, whilst reproductive performance is highly responsive to changes in energy supply [12]. Delayed implantation causes the length of the gestation from mating to vary, the range usually being between 39 and 74 days, while the true gestation, i.e. the period from implantation until parturition, lasts $30 \pm 3$ days [13]. The mink gives birth to altricial kits with limited locomotor ability and negligible body energy stores [14]. Relatively high kit losses are common in the first few days of life [15], especially when kits are small, or milk yield is insufficient [16]. Suckling is established soon after birth and, provided milk yield is sufficient, kits have a high capacity for rapid growth [14,17]. Because mink kits are entirely dependent on milk from the dam for the first 3 to 4 weeks of life, the milk yield of the dam is of utmost importance for kit survival and growth $[14,16]$. Therefore, if the milk yield is compromised by malnutrition in mink dams during gestation this might constitute a high risk of impaired growth in the kits. The precise dietary protein requirement of pregnant mink is not known, however, severe protein restriction (crude protein, CP: $14 \%$ of metabolizable energy, ME) during late gestation results in higher occurrence of barrenness, fewer kits per mated female, and reduced birth weight of the offspring, while there is a tendency for a greater number of kits born alive to adequately fed (AP) dams [11]. Furthermore, severe protein restriction causes changes not only in the F1-generation but also induces an increased birth weight and altered hepatic gene expression in the F2-generation [18].

The objective of the present study was to implement a level of protein restriction during late gestation in mink, which was mild enough to avoid the adverse effects on reproductive performance and kit mortality resulting from a severely protein restricted diet [11], yet restrictive enough to cause alterations in the metabolic profile of the mink offspring. In so doing, it was our aim to develop and investigate a mink LP model. The effects of a restricted- or adequate protein diet during late gestation on reproductive performance of dams, somatic growth and organ development in fetuses, as well as body and organ weight in kits at birth through to weaning were studied. The working hypothesis being that maternal protein restriction (CP: $19 \%$ of ME) during late gestation induces metabolic changes in the offspring, as evidenced by an impaired growth profile, yet has no adverse effect on reproductive performance.

\section{METHODS}

The animal experiments were conducted in accordance with the guidelines of the European Convention for the Protection of Vertebrate Animals used for Experimental and Other Scientific Purposes as well as the Animal Experimentation Act under Danish national legislation. The experiments were approved by the Danish Animal Experiments Inspectorate, License number 2005/561-994.

\subsection{Animals}

Twenty-three one-year and forty-two two-year old female wild type mink were mated according to the $1+9$ (starting on the $6^{\text {th }}$ of March) and the $1+1$ (starting on the $16^{\text {th }}$ of March) mink mating system, respectively [19]. The differentiated mating times enabled the expected parturition time to be spread out over approximately 14 days, rather than being concentrated to just a few days. Thirty-five females were given a low protein (LP) diet while another group of thirty females were given an adequate protein (AP) diet from the $13^{\text {th }}$ of April, when it was anticipated that implantation was completed, and until parturition, i.e. corresponding to the last two-thirds of gestation. Four females from each dietary treatment group were euthanized 14 days after the beginning of the differential dietary treatment, which was equivalent to 43 days after the last mating, for organ and fetus collection. The remaining fifty-seven females gave birth over a span of 12 days starting on the $26^{\text {th }}$ of April and were used to study the reproductive performance. Four females in each dietary treatment group were barren. The offspring from the remaining forty-nine females were monitored routinely for bodyweight; i.e. weighed on the same day each week as the day on which they were born, from birth until weaning (7 weeks old).

Ten pregnant females from each treatment group were used in balance and respiration experiments once before parturition, and again during the first and the third weeks post partum, respectively. These weeks will subsequently be referred to as early and peak lactation as defined by Tauson and coworkers [16]. Due to causes not related to the balance experiment one female from each treatment group was omitted from the experiment in the first week of lactation. Hence, in the experiment of the first week of lactation there were nine females per treatment group. Litter size per dam was standardized to 6 kits within the first three days of parturition. Kits were observed to suckle throughout the two balance periods post partum, however, measurements of milk yield were not undertaken.

Animals taking part in the balance- and respiration experiments were transferred from the experimental mink farm to the animal laboratory facility where they were kept in metabolism cages under natural daylight 
conditions $\left(55^{\circ} \mathrm{N} 12^{\circ} \mathrm{E}\right)$ and at an ambient temperature of between $17^{\circ} \mathrm{C}-20^{\circ} \mathrm{C}$. During balance periods, each animal remained in the same metabolism cage it had become acclimated to. When indirect calorimetry measurements were performed the animals were transferred to a respiration unit in an adjacent laboratory building.

\subsection{Dietary Treatments}

Animals were fed ad libitum once a day and had free access to drinking water. A standard mink diet (Sjaellands Pelsdyrfoder A.m.b.a., Stårup, Denmark) was fed to all mink dams until the $13^{\text {th }}$ of April when implantation was considered to be complete in all dams, and immediately post partum throughout the lactation period. Two different experimental diets, AP (adequate protein content; crude protein:fat:carbohydrate ratio of $31 \%: 55 \%$ : 14\% of ME) and LP (low protein content; 19:49:32\% of ME), were mixed on site (Table 1). The AP and LP diets were given for $21.8 \pm 6$ days (mean \pm range) and $20.6 \pm$ 6 days, respectively, from the $13^{\text {th }}$ of April until parturition. The ingredients used to mix the two diets were identical and the diets were iso-energetic. Fresh chicken was minced (chopping machine; BIZERBA, BizerbaWerke Wilhelm Krau GmbH \& Co., Hamburg, Germany) and mixed with the other feed ingredients (food mixer; Bjørn Varimixer, Denmark). The diets were made from the same type of ingredients as the diets made for the study by Matthiesen and coworkers [11] and are therefore considered to contain a somewhat higher amount of essential amino acids as reported in that study.

All experimental diets were prepared on site at the same time, and frozen immediately in plastic bags apportioned by day ration weight, until required. After parturition, all animals were fed a standard mink diet. In early lactation, the calculated contribution of protein, fat, and carbohydrate was 36\%:47\%:17\% of ME (dry matter (DM) $343 \mathrm{~g} \cdot \mathrm{kg}^{-1}$, crude protein (CP) $156 \mathrm{~g} \cdot \mathrm{kg}^{-1}$, fat 70 $\mathrm{g} \cdot \mathrm{kg}^{-1}$, and carbohydrate (CHO) $80 \mathrm{~g} \cdot \mathrm{kg}^{-1}$ ), whilst the peak lactation diet was 46\%:40\%:14\% of ME (DM 322 $\mathrm{g} \cdot \mathrm{kg}^{-1}, \mathrm{CP} 162 \mathrm{~g} \cdot \mathrm{kg}^{-1}$, fat $51 \mathrm{~g} \cdot \mathrm{kg}^{-1}$, and CHO $\left.66 \mathrm{~g} \cdot \mathrm{kg}^{-1}\right)$.

\subsection{Balance and Respiration Experiments}

Prior to the balance experiments, animals were acclimatized to the metabolic cage and the laboratory facilities for a three-day adaptation period. The balance experiments consisted of a four-day period, where feed supply was recorded, and feed refusals and spillage, faeces, and urine were quantitatively collected, weighed, and stored at $-20^{\circ} \mathrm{C}$. Urine was collected in $10 \mathrm{ml}$ of $5 \%$ sulphuric acid solution. After removal and storage of faeces, residues were collected by rinsing the collection screens and funnels in a $1 \%$ citric acid solution to minimize nitrogen losses. During the acclimatization and
Table 1. Feed ingredient distribution $\left(\mathrm{g} \cdot \mathrm{kg}^{-1}\right)$ and analysed chemical composition of diets; adequate protein (AP) and restricted protein (LP). Nutrient distributions as a \% of metabolizable energy ( $\% \mathrm{ME})$ in the diets are given for crude protein (CP), fat, and carbohydrate (CHO).

\begin{tabular}{|c|c|c|}
\hline & \multicolumn{2}{|c|}{ Dietary treatment } \\
\hline & $A P$ & $L P$ \\
\hline \multicolumn{3}{|c|}{ Experimental dietary composition $\left(\mathrm{g} \cdot \mathrm{kg}^{-1}\right)$} \\
\hline Fresh chicken $^{*}$ & 455 & 338 \\
\hline Fishmeal & 114 & 42 \\
\hline Sugar beat pulp & 23 & 17 \\
\hline Steam rolled oats & 30 & 88 \\
\hline Potato mash powder & 30 & 34 \\
\hline Corn starch, gelatinized & 30 & 80 \\
\hline Corn oil & 46 & 50 \\
\hline Vitamin and mineral mixture $^{\dagger}$ & 3 & 3 \\
\hline Water & 269 & 348 \\
\hline \multicolumn{3}{|c|}{ Experimental diet chemical composition } \\
\hline Dry matter $(\mathrm{DM}), \mathrm{g} \cdot \mathrm{kg}^{-1}$ & 408 & 399 \\
\hline Ash, $g \cdot \mathrm{kg}^{-1} \mathrm{DM}$ & 71 & 54 \\
\hline $\mathrm{CP}, \mathrm{g} \cdot \mathrm{kg}^{-1} \mathrm{DM}$ & 426 & 273 \\
\hline Fat, $\mathrm{g} \cdot \mathrm{kg}^{-1} \mathrm{DM}$ & 288 & 253 \\
\hline $\mathrm{CHO}, \mathrm{g} \cdot \mathrm{kg}^{-1} \mathrm{DM}$ & 215 & 420 \\
\hline Gross energy, MJ/kg DM & 24.7 & 23.3 \\
\hline $\mathrm{ME}, \mathrm{MJ} / \mathrm{kg} \mathrm{DM}$ & 20.2 & 19.9 \\
\hline CP:fat:CHO ratio (\% of ME) & $31: 55: 14$ & $19: 49: 32$ \\
\hline
\end{tabular}

${ }^{*}$ Chicken prepared for human consumption; absence of head, feet, feathers, and entrails. 'Per kg vitamin and mineral mixture supplement: retinol 2800500 IU, Cholecalciferol 280,000 IU, $\alpha$-tocopherol acetate $24021 \mathrm{IU}$, thiamine $10,002 \mathrm{mg}$, riboflavin $4801 \mathrm{mg}$, nicotiamide $8002 \mathrm{mg}$, pyridoxine $3201 \mathrm{mg}$, D-pantothenic acid $3207 \mathrm{mg}$, biotin 80,012 $\mu \mathrm{g}$, folic acid $241 \mathrm{mg}$, choline chloride 60,001 mg, cyanocobalamin 16,008 $\mu \mathrm{g}$, para-aminobezoic acid 800 $\mathrm{mg}$, betaine 33,600 mg, Fe $\left(\mathrm{FeSO}_{4}\right) 19,712 \mathrm{mg}, \mathrm{Cu}\left(\mathrm{CuSO}_{4}\right) 1025 \mathrm{mg}, \mathrm{Zn}$ $(\mathrm{ZnO}) 12,561 \mathrm{mg}$, and $\mathrm{Mn}(\mathrm{MnO}) 6238 \mathrm{mg}$ (Trow Nutrition Denmark A/S, Denmark).

balance periods the animals were fed ad libitum once daily and had free access to drinking water. Feeding, change of water, and collection was performed daily between 08:00 and 10:00 hours.

Respiration experiments were performed on all animals once per balance period, over a period of 22 hours, by indirect calorimetry in an open-air circulation respiration unit [20]. Dams and their kits were measured together throughout the lactation period. Mink dams and kits were weighed at the beginning- and the end of the balance period, as well as on the day of the 22 -hour respiration experiment.

\subsection{Chemical Analyses}

Dry matter and nitrogen $(\mathrm{N})$ content was analysed in wet samples of the experimental diets and of the conventional feed during lactation, and DM was analysed in wet 
samples of the feed residues, while ash was analysed on dried feed samples. Analysis of DM and ash allowed determination of organic matter content in the diets. It was assumed that the organic matter of the feed residues held the same proportions of $\mathrm{CP}$, fat, and $\mathrm{CHO}$ as the organic matter of the various diets. Samples of diets and faecal matter were freeze-dried and analysed for DM, ash, fat, and gross energy (GE), while urine and citric acid rinse were analysed for content of N. Dry matter was found by evaporation at $105^{\circ} \mathrm{C}$ overnight (10 hours), and ash was determined by incineration overnight at $525^{\circ} \mathrm{C}$ (10 hours). Fat content was determined by hydrolysis in $3 \mathrm{M}$ hydrochloric acid and subsequent fat extraction with petroleum ether using the Soxtec system 1047 hydrolysing unit tecator and the 1043 extraction unit (Foss, Höganäs, Sweden), respectively. Samples were analysed for $\mathrm{N}$ content by the micro-Kjeldahl analysis technique using a 2020 Digestor at $420^{\circ} \mathrm{C}$ and the $2200 \mathrm{Kjeltec}$ auto distillation unit (Foss, Höganäs, Sweden). The content of $\mathrm{CP}$ was calculated as $\mathrm{N} \times 6.25$. Carbohydrate content was calculated by difference: $\mathrm{CHO}=\mathrm{DM}-\mathrm{Ash}$ - CP - Fat. Gross energy content was determined in an adiabatic bomb calorimeter using the IKA Calorimeter System (IKA Gmbh \& Co. KG, Staufen, Germany).

\subsection{Calculations}

Calculations of urinary energy (UE), ME, retained energy (RE), retained $\mathrm{N}(\mathrm{RN})$, and the non-protein respiratory quotient $\left(\mathrm{RQ}_{\mathrm{np}}\right)$ were performed as previously described [11]. The heat production (HE) calculation was based on [21], and calculations of the oxidation of protein, fat, and carbohydrate (OXP, OXF, and OXCHO, respectively) as a percentage of $\mathrm{HE}$ were based on [22]. Substrate oxidation formulas were validated for $\mathrm{RQ}_{\mathrm{np}}$ values between 0.707 and 1.0 and above 1.0 [22], and below 0.707 [20]. Where $R_{\text {np }}$ was below 0.707 the $\mathrm{OXCHO}$ was set to zero. Fat oxidation was consequently calculated as the net value of $\mathrm{CHO}$ oxidation plus the value of fat oxidation [20]. Heat production of lactating mink dams was calculated such that the total HE of the dam and her litter was multiplied by the ratio of dam to dam + kit metabolic body size to give the heat production of the dam alone. Milk yield per lactating mink dam was calculated based on measurement data of kit weight gain during the lactation period and estimates for milk intake in relation to kit weight gain (lactation week 1:3.5 g milk/g body gain, lactation week $3: 5.0 \mathrm{~g}$ milk/g body gain; [16]). Milk energy (LE) was calculated using the chemical composition of mink milk [16] and the estimated milk yield of the dams. In lactating dams energy and $\mathrm{N}$ retained or mobilized from the body (RE and $\mathrm{RN}$, respectively) were calculated as $\mathrm{RE}=(\mathrm{ME}$ intake of the dam $-\mathrm{HE}$ of the dam $-\mathrm{LE})$ and $\mathrm{RN}=($ digested $\mathrm{N}-$ uri- nary $\mathrm{N}-\mathrm{N}$ in milk).

Kit body weights were recorded and the instantaneous relative growth rate $(k)$ of the kits was calculated according to Brody [23]:

$$
k=\left(\ln W_{2}-\ln W_{1}\right) /\left(A_{2}-A_{1}\right)
$$

where $W_{1}$ and $W_{2}$ are kit weights in $\mathrm{g}$ and $A_{1}$ and $A_{2}$ are the age of the kits in days at the beginning and at the end of the periods. The relative growth rate in percent per day is found by multiplication of the $k$-value with 100 . The calculations were performed for one-week intervals from birth and until 49 days of age.

\subsection{Organ and Tissue Collection}

Pregnant dams and their fetuses. Eight pregnant oneyear old mink dams, four from each dietary treatment group, were euthanized 43 days after mating and after 14 days of dietary treatment. Anaesthezia was achieved by intramuscular injection of $0.2 \mathrm{ml} \cdot \mathrm{kg}^{-1}$ of Ketaminol and $0.1 \mathrm{ml} \cdot \mathrm{kg}^{-1}$ of Narcoxyl $\left(50 \mathrm{mg} \cdot \mathrm{ml}^{-1}\right.$ and $20 \mathrm{mg} \cdot \mathrm{ml}^{-1}$, respectively, Intervet International B.V. Boxmeer, The Netherlands). Upon loss of interdigital-, palpebral-, and corneal reflexes the mink dams were euthanized by cardiac excision. Liver and uteri with fetuses were quickly excised. The body, liver, and uterus weights were recorded for all dams. All dams were found to be pregnant. Fetuses were retrieved from the uteri, weighed, and their body length was measured before euthanazia by decapitation. The livers from two fetuses per dam were retrieved and weighed. The organs were immediately frozen in liquid nitrogen and stored at $-80^{\circ} \mathrm{C}$.

Newly born and young kits. At days 1, 2, 14 and 28 post partum, 4 male kits from each dietary group were weighed, anaesthetized as described above for the pregnant mink dams, and euthanized by dorsal decapitation in 1,2 , and 14 days old kits. Kits of 28 days of age were anaesthetized and euthanized as described above for the pregnant mink dams. Liver was collected from 1 and 2 days old mink kits and weighed. Liver, kidney, and pancreas were collected from 14 and 28 day old kits, and weighed. The organs were immediately frozen in liquid nitrogen and stored at $-80^{\circ} \mathrm{C}$.

\subsection{Statistical Analyses}

Data, which were normally distributed and of equal variance, were analyzed statistically using the Mixed Procedure in SAS as repeated measures (SAS/STAT ${ }^{\circledR}$ software, version 9.2, SAS Institute INC., Cary, NC, USA) according to the model

$$
Y_{i j k}=\mu+\alpha_{i}+\beta_{j}+(\alpha \beta)_{i j}+\varepsilon_{i j k}
$$

where $\mu$ represents the general mean, $\alpha_{i}$ represents the fixed effect of either gestation or stage in lactation, $\beta_{j}$ is 
the fixed effect of the dietary intervention in late gestation (AP or LP), $(\alpha \beta)_{i j}$ is the interaction between fixed effects, and $\varepsilon_{i j k}$ represents the residual error $\sim N\left(0, \sigma_{i}^{2}\right)$. Animal was the subject in the analysis. Where the initial residual and Cook's Distance plots suggested a non-random structure to the data, further analysis was performed on log-transformed data, and the following interpretation was carried out on back-transformed mean estimates. Model reduction was performed for non-significant effects. Pair-wise comparison of the LSmeans was carried out using the PDIFF option. Power tests were conducted using GrapPad StatMate 2 (Version 2.0a 2004 for MacIntosh, GraphPad software, Inc.). Data are presented as LSmeans \pm SE. Differences between the means were considered significant at the $5 \%$ level, i.e. $P<0.05$.

\section{RESULTS}

Results concerning nutrient intake and various metabolic parameters are given in relation to metabolic body size for comparative purposes, while results regarding organ data are given as the mass of the organ and as the percentage of organ to body weight.

\subsection{Nutrient Intake}

During the period of differentiated feeding in late gestation, LP dams had a lower intake of CP $(8.0 \pm 0.4$ $\left.\mathrm{g} \cdot \mathrm{kg}^{-0.75} \cdot \mathrm{day}^{-1} ; P<0.01\right)$ and a higher intake of $\mathrm{CHO}$ $\left(12.3 \pm 0.6 \mathrm{~g} \cdot \mathrm{kg}^{-0.75} \cdot\right.$ day $\left.^{-1} ; P<0.001\right)$ than AP dams (CP: $14.2 \pm 1.6 \mathrm{~g} \cdot \mathrm{kg}^{-0.75} \cdot \mathrm{day}^{-1}$; CHO: $7.2 \pm 0.8 \mathrm{~g} \cdot \mathrm{kg}^{-0.75} \cdot$ day $\left.^{-1}\right)$, which reflected the nutrient composition of the diets during late gestation.

Protein restriction during gestation had no effect on nutrient intake during lactation, however, nutrient intake increased from gestation and throughout the lactation period (gestation to lactation week 1: $P<0.001$, and lac- tation week 1 to week 3: $P<0.01$ ), reflecting the increasing demand for nutrients for lactation purposes.

\subsection{Nitrogen Metabolism}

The restricted protein dietary treatment affected the nitrogen metabolism in the period of the differentiated feeding during gestation, such that LP dams digested $46 \%$ less nitrogen (DN; $P<0.01)$, had $48 \%$ lower UN $(P$ $<0.01$ ), and $40 \%$ lower RN (including $\mathrm{N}$ for fetal development; $P<0.05$ ) than AP dams (Figure 1).

During lactation there was, however, no effect of the late gestation protein restriction. As milk yield increased over the lactation period $\mathrm{DN}$ increased in concert with increased nutrient intake from $3.10 \mathrm{~g} \cdot \mathrm{kg}^{-0.75}$ to $5.16 \mathrm{~g} \cdot \mathrm{kg}^{-0.75}$ $(P<0.001)$. Retained nitrogen (calculated to exclude the estimated amount of $\mathrm{N}$ excreted in the milk) decreased from $-0.22 \mathrm{~g} \cdot \mathrm{kg}^{-0.75}$ to $-0.72 \mathrm{~g} \cdot \mathrm{kg}^{-0.75}(P<0.05)$, while the estimated content of $\mathrm{N}$ excreted in the milk increased from $1.18 \mathrm{~g} \cdot \mathrm{kg}^{-0.75}$ to $2.31 \mathrm{~g} \cdot \mathrm{kg}^{-0.75}(P<0.001)$.

\subsection{Energy Metabolism}

During the period of differentiated feeding in late gestation there was no difference in ME intake (LP: $615 \pm$ $27 \mathrm{~kJ} \cdot \mathrm{kg}^{-0.75} \cdot \mathrm{day}^{-1}$; AP: $696 \pm 75 \mathrm{~kJ} \cdot \mathrm{kg}^{-0.75} \cdot \mathrm{day}^{-1}, P>$ $0.05)$. The restricted protein diet also did not affect body weight during the feeding intervention in late gestation. Likewise, HE and RE (calculated to exclude energy excreted in the milk) were not affected by the treatment, both during the dietary intervention and throughout lactation, where also energy contained in milk (LE) was not affected.

During lactation, ME intake increased by $31 \%$ ( $P=$ 0.001 ), while HE increased by $14 \%$ (Table 2 ). The estimated LE increased by $135 \%(P<0.001)$ as lactation progressed, and conversely, calculated RE decreased
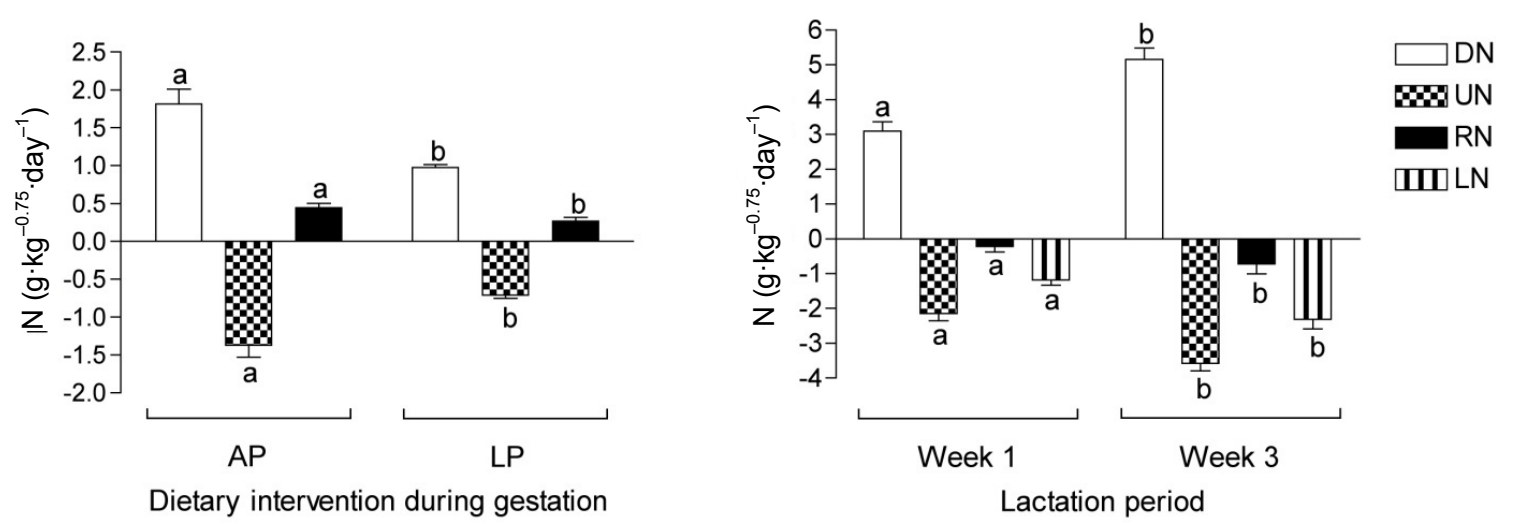

Figure 1. Nitrogen metabolism in pregnant dams fed either an adequate protein diet (AP) or a low protein diet (LP) in the last part of gestation, and lactating dams in the first and third week of lactation fed a conventional mink farm diet. $\mathrm{DN}$ : digested nitrogen; UN: urinary nitrogen; RN: retained nitrogen (note in lactation period, RN is calculated by subtraction of estimated milk nitrogen content); LN: estimated milk nitrogen. Different superscripts denote statistical differences; $P<0.05$. 
Table 2. Energy metabolism 1 and 3 weeks post partum in lactating dams. Metabolic traits are given as metabolizable energy (ME), heat production (HE), retained energy (RE; excluding energy estimated for milk production, LE), non-protein respiratory quotient $\left(\mathrm{RQ}_{\mathrm{np}}\right)$, and substrate oxidation of protein $(\mathrm{OXP})$, fat (OXF), and carbohydrate (OXCHO) as a percentage of HE of dams fed an adequate protein (AP) or a low protein (LP) diet in the last $21.2 \pm 3.3$ days before parturition. Different superscript letters within a column denote significant differences. Differences are considered significant where $P<0.05$.

\begin{tabular}{|c|c|c|c|c|}
\hline & \multicolumn{2}{|c|}{ Lactation week } & \multicolumn{2}{|c|}{$P$-value, effect of } \\
\hline & Lactation week $1,(\mathrm{n}=18)$ & Lactation week $3,(\mathrm{n}=20)$ & Treatment & Week \\
\hline \multicolumn{5}{|c|}{ Body weight dams, $g$} \\
\hline $\mathrm{AP}$ & $1485 \pm 40^{\mathrm{a}}$ & $1363 \pm 51^{\mathrm{a}}$ & $<0.05$ & NS \\
\hline LP & $1539 \pm 29^{\mathrm{a}}$ & $1489 \pm 31^{\mathrm{b}}$ & & \\
\hline \multicolumn{5}{|c|}{ Energy metabolism } \\
\hline $\operatorname{ME}\left(\mathrm{kJ} \cdot \mathrm{kg}^{-0.75}\right)$ & $1052 \pm 61$ & $1377 \pm 71$ & NS & 0.001 \\
\hline $\mathrm{HE}\left(\mathrm{kJ} \cdot \mathrm{kg}^{-0.75}\right)$ & $692 \pm 18$ & $788 \pm 26$ & NS & $<0.01$ \\
\hline $\mathrm{LE}\left(\mathrm{kJ} \cdot \mathrm{kg}^{-0.75}\right)$ & $354 \pm 32$ & $832 \pm 66$ & NS & $<0.001$ \\
\hline \multicolumn{5}{|l|}{ estimated value } \\
\hline $\mathrm{RE}\left(\mathrm{kJ} \cdot \mathrm{kg}^{-0.75}\right)$ & $6 \pm 48$ & $-243 \pm 67$ & NS & $<0.01$ \\
\hline $\mathrm{RQ}_{\mathrm{np}}$ & $0.74 \pm 0.01$ & $0.72 \pm 0.01$ & NS & NS \\
\hline \multicolumn{5}{|c|}{ Substrate oxidation, \% of $H E$} \\
\hline OXP & $21 \pm 1$ & $22 \pm 1$ & NS & NS \\
\hline OXF & $69 \pm 2$ & $74 \pm 2$ & NS & NS \\
\hline $\mathrm{OXCHO}$ & $10 \pm 2$ & $4 \pm 1$ & NS & $<0.05$ \\
\hline
\end{tabular}

from $6 \mathrm{~kJ} \cdot \mathrm{kg}^{-0.75}$ to $-243 \mathrm{~kJ} \cdot \mathrm{kg}^{-0.75}$ from early to peak lactation. The negative energy balance in the dams was reflected in the pooled body weights, which decreased from early to peak lactation $(P<0.05)$. Gestational protein restriction did not affect body weight during early lactation, however, in peak lactation LP dams weighed $9 \%$ more than AP dams $(P<0.05)$.

\subsection{Substrate Oxidation}

The nutrient composition of the differentiated diets (Table 1) is reflected in the substrate oxidation of the mink dams during gestation, such that LP dams oxidized less protein $(P=0.001)$ but more carbohydrate $(P<0.05)$ as a percentage of HE than AP dams (OXP: $12 \%$ vs. $23 \%$ of HE; OXCHO: $37 \%$ vs. $26 \%$ of HE). The OXF was not affected by the dietary treatment in the pregnant mink during gestation. Likewise, gestational protein restriction had no effect on substrate oxidation during lactation. Carbohydrate oxidation decreased from early to peak lactation $(P<0.05)$ (Table 2), however, OXP and OXF did not change throughout the lactation period.

\subsection{Reproductive Performance and Kit Birth Weight}

In the last $21.2 \pm 3.3$ days before parturition the pregnant mink dams were fed either a low protein or an adequate protein diet. While the dietary intervention proved to have no effect on the reproductive performance, there was a significant effect of the protein restriction on the body weights of the offspring at birth, such that kits hav- ing been exposed to protein restriction during fetal life (FLP1) weighed $8.5 \%$ less than kits having been exposed to an adequate protein supply (FAP1) in utero $(P<0.001)$ (Table 3). There was an effect of the fetal protein restriction within sex on birth weight, causing lower body weights in both female $(P<0.001)$ and male $(P<0.01)$ FLP1 animals. There were, however, no differences in body weight between sex within each treatment group. During the first week of lactation LP dams lost 1.8 kits per litter, while AP dams lost 1.0 kits per litter $(P=0.1)$, and kit loss per litter from birth until weaning was 33.3\% in the LP dams and $20.6 \%$ in the AP dams, the difference being statistically significant $(P<0.05)$.

\subsection{Kit Body Weight}

The kit growth performance post partum is shown in Figure 2. There was no effect of litter size on the kit body weights. From birth and until 21 days of age there was no effect of gender on the body weight of the kits, however, from 21 days and onwards, male kits were heavier than female kits within both treatment groups ( $P$ $<0.001)$.

At 7 days of age, females weighed the same (Figure 2(a)), but by 14 days of age, because female FLP1 kits had gained less weight than FAP1 kits (Figure 2(b)), FLP1 females were $10.6 \%$ lighter $(P<0.01)$. Catch-up growth of the FLP1 female kits occurred between day 14 and 21 as evidenced by a $73 \%$ weight increase $(P<0.05)$. From 21 days of age and until weaning female kit weight was not affected by the maternal protein restriction. 
Table 3. Reproductive performance of dams $(n=49)$ fed either a low protein (LP) or an adequate protein (AP) diet, during the last two thirds of gestation ( $21.2 \pm 3.3$ days before parturition). Birth weights of kits born alive having been exposed to a low protein (FLP1) or an adequate protein (FAP1) diet in utero. Differences are considered significant where $P<0.05$.

\begin{tabular}{lccc}
\hline & Late gestation dietary treatment & $P$-value, effect of \\
\cline { 2 - 4 } & $A P$ & $L P$ & Treatment \\
\hline Reproductive performance & & & NS \\
Barren females, $\%$ & 11.5 & 12.9 & NS \\
Kits per litter & $8.3 \pm 0.6$ & $7.5 \pm 0.5$ & NS \\
Kits per mated female & $7.3 \pm 0.4$ & $6.5 \pm 0.3$ & NS \\
Stillborn kits, $\%$ & 21.9 & 22.2 & NS \\
Number of live kits per litter & & & $<0.05$ \\
Parturition & $6.8 \pm 0.5$ & $6.0 \pm 0.5$ & $<0.05$ \\
7 days post partum & $5.8 \pm 0.4$ & $4.2 \pm 0.5$ & NS \\
21 days post partum & $5.6 \pm 0.4$ & $4.1 \pm 0.5$ & \\
49 days post partum & $5.4 \pm 0.4$ & $4.0 \pm 0.5$ & $<0.001$ \\
Kit birth weight, $n=305$ & & & 0.01 \\
Mean live weight, g & $10.6 \pm 2.0$ & $9.7 \pm 2.1$ & 0.001 \\
Female weight, g & $10.5 \pm 0.3$ & $9.6 \pm 0.2$ & \\
Male weight, g & $10.8 \pm 0.2$ & $9.7 \pm 0.3$ & \\
\hline
\end{tabular}

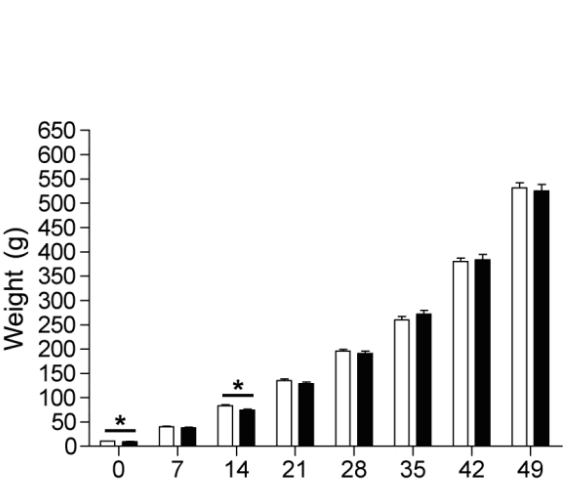

(a)

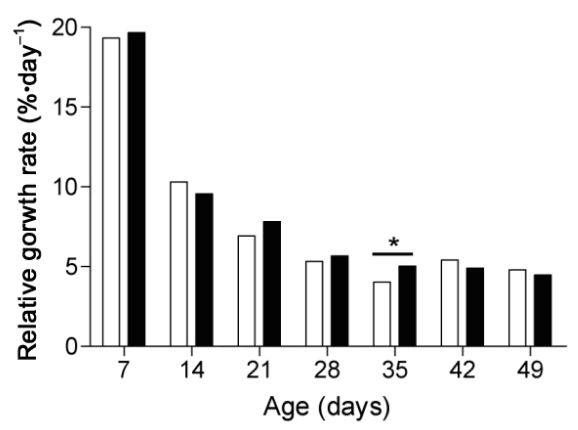

(b)

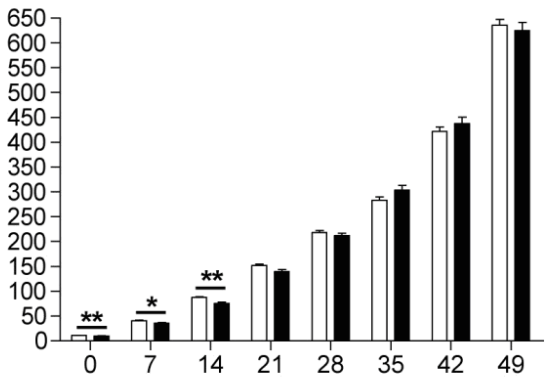

(c)

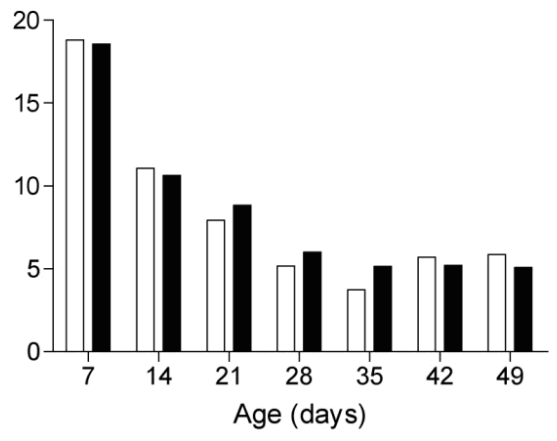

(d)

Figure 2. Mink kit body weights and relative growth rate per day from 0 to 49 days after birth. Body weights of (a) female and (c) male mink kits exposed to an adequate protein (FAP1) or a low protein diet (FLP1) during gestation. All body weights increased significantly from week to week; $P<0.001$. Relative growth rate per day in (b) female and (d) male mink kits where different superscripts denote significant progressive differences within treatment; $P<0.05$. Bars denote differences between treatment groups where ${ }^{*}$ is $P<0.05$ and $^{* *}$ is $P<0.01$. 
FLP1 male kits weighed less than FAP1 male kits at day $7(11 \%, P<0.05)$ and $14(14 \%, P<0.01$; Figure 2(c)), however, because FAP1 males had a tendency to lower weight gain $(P=0.1)$ than FLP1 kits between 14 and 21 days of age (Figure 2(d)), body weights were the same by 21 days of age. As with the female kits, male kit body weight was not affected by the maternal protein restriction from 21 days of age until weaning.

The relative growth rate of the male mink kits from birth and until weaning was not affected by the in utero protein restriction and was significantly higher $(P<0.01)$ than that of the female kits in the period from 42 to 49 days, resulting in $18 \%$ heavier males at the time of weaning $(P<0.001)$. Likewise, the relative growth rate of female mink kits was the same in FAP1 and FLP1 kits from birth and until 28 days of age. In the period 28-35 days of age, however, the relative growth rate of the female FLP1 kits was higher than that of the FAP1 female kits $\left(5 \% \cdot\right.$ day $^{-1}$ vs $4 \% \cdot$ day $\left.^{-1} ; P<0.05\right)$. The maximum growth rate for all kits occurred between birth and 7 days of age and was $19 \%$ ranging from $11 \%$ to $28 \%$. The relative growth rate of the mink kits from birth until 21 days was $12 \%$, while it was $5 \%$ from 21 to 49 days of age. In the period between 28 and 35 days of age the relative growth rate was less than the growth rate of the following periods $(P<0.001)$.

\subsection{Dam, Fetus, and Kit Organ Collection}

Fetal litters within the LP group differed in body weight and length (Figure 3) with one litter being lighter $(3.1 \pm 0.2 \mathrm{~g}$ ranging from $2-4.3 \mathrm{~g})$ and shorter $(3.9 \pm 0.1$ $\mathrm{cm}$ ranging from $3.0-4.5 \mathrm{~cm})$ than the other LP litters $(P$ $<0.001$ and $P<0.01$, respectively). Another LP litter was heavier $(13.8 \pm 0.4 \mathrm{~g}$ ranging from $12.0-15.2 \mathrm{~g})$ and longer $(8.4 \pm 0.1 \mathrm{~cm}$ ranging from $8.0-9.0 \mathrm{~cm})$ than the very light litter $(P<0.001)$, but not different from the remaining LP litters. The body weights and lengths of the two remaining LP litters of fetuses were the same $(8.6 \pm$ $0.2 \mathrm{~g}$ with a range of $7.9-9.2 \mathrm{~g}$ and $6.6 \pm 0.1 \mathrm{~cm}$ ranging from $6.5-7.0 \mathrm{~cm}$ ).

Three of the AP litters did not differ in terms of body weight $(10.5 \pm 0.3 \mathrm{~g}$ ranging from $6.6-14.0 \mathrm{~g})$ and length $(7.4 \pm 0.1 \mathrm{~cm}$ ranging from $5.5-9.0 \mathrm{~cm})$, however, they were lighter but not shorter than the remaining AP litter weighing $16.7 \pm 0.6 \mathrm{~g}$ (ranging from 14.1 - $19.9 \mathrm{~g}$; $P<0.001)$.

The LP fetuses weighed $28 \%$ less and were $18 \%$ shorter than the fetuses in the AP group $(P<0.001$, Table 4). The body length to body weight ratio in the fetuses did not, however, differ between treatment groups

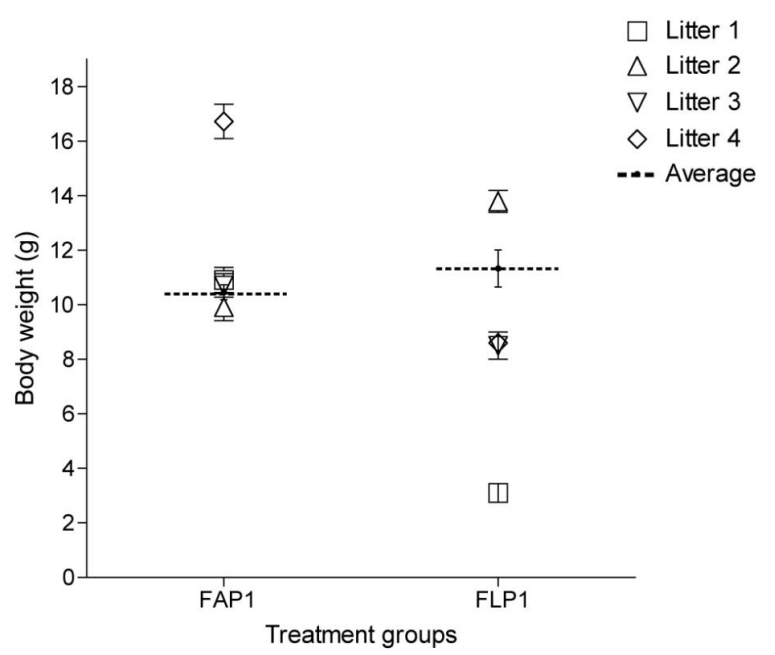

Figure 3. Average fetal body weights from adequate protein (AP) or protein restricted (LP) dams during late gestation. Symbols are paired within treatment between body weight and show the individual litter averages.

Table 4. Uterus weights (including fetuses) of the dams, plus the body weights and lengths of the fetuses, 43 days after mating, in dams fed either an adequate protein (AP) or a protein restricted (LP) diet during late gestation. Differences are considered significant where $P<0.05$.

\begin{tabular}{lccc}
\hline & \multicolumn{2}{c}{ In utero dietary treatment } & $P$-value, effect of \\
\cline { 2 - 4 } & $A P$ & $L P$ & Treatment \\
\hline Dam, $n=8$ & & & NS \\
Liver, g & $44.1 \pm 3.0$ & $39.6 \pm 1.1$ & NS \\
Liver, \% of body weight & $2.3 \pm 0.2$ & $2.2 \pm 0.1$ & $<0.05$ \\
Total uterus, $g$ & $213.2 \pm 11.9$ & $142.5 \pm 22.6$ & NS \\
Litter size (live, dead \& reabsorbed) & $11.0 \pm 1.3$ & $7.8 \pm 1.8$ & NS \\
Number of live fetuses & $10.8 \pm 1.1$ & $6.8 \pm 1.8$ & NS \\
Number of reabsorbed fetuses & $0.3 \pm 0.3$ & $1.0 \pm 0.6$ & $<0.001$ \\
Fetuses, $n=70$ & & & $<0.001$ \\
Fetus body weight, g & $11.6 \pm 0.5$ & $8.3 \pm 0.9$ & NS \\
Fetus length, cm & $7.6 \pm 0.1$ & $6.2 \pm 0.4$ & 74.7 \\
Body length: body weight, \% & 65.5 & & \\
\hline
\end{tabular}


indicating that although the LP fetuses were smaller than those of the AP group, they were of the same proportions.

The uteri of the LP dams were 33\% lighter than those of the AP dams $(P<0.05)$. Moreover, although not statistically significant, AP uteri contained about 4 viable fetuses more than in LP uteri, which might represent a biologically important difference. Liver mass and liver mass in relation to body mass in the dams (Table 4) as well as in their fetuses (Figure 4(a)) was unaffected by the protein restriction.

Liver, pancreas, and kidney mass and mass in relation in body mass from birth until 28 days of age was not affected by the protein restriction in utero (Figure 4). The liver weight increased in proportion to body weight, which was reflected in the increase in liver mass at 14 and 28 days of age $(P<0.001$, respectively). The kidney and pancreas mass likewise increased with age, however, not to the same extent as kit body weight, resulting in a decrease of organ mass in relation to body mass of $68 \%$ in kidney $(P<0.001)$ and $60 \%$ in the pancreas $(P<$ $0.01)$.

\section{DISCUSSION}

This study reports that the body weight of offspring born to mink dams fed a protein restricted diet during late gestation (FLP1) was lower than that of control kits (FAP1) from birth up to 21 days of age. However, organ to body weight ratios were the same, indicating that FLP1 kits were proportional to FAP1 kits, just smaller in size. Of equal importance was the finding that protein restriction during the period of differentiated feeding resulted in a higher kit loss from birth to weaning.

Unfortunately, restrictions on the number of animals available for this study limited the sampling size and as a consequence the power of the statistical analyses on reproductive performance was lower than the desired $80 \%$. Thus, despite differences between treatments occasionally being biologically significant, other aspects of the reproductive performance were not statistically significant.

\subsection{Mink Dam Adaptation to Differentiated Protein Supply during Gestation}

The present study found no effect of gestational protein restriction on mink dam liver mass. In contrast, protein restriction during lactation has been shown to cause a significant reduction in mink dam liver mass [24], and additionally, liver mass has been found to be reduced in response to a protein restricted diet in rat pups [10]. It is likely that this disagreement might be due not only to differences in the protein content of the diet but also the duration of the dietary intervention, which lasted through-

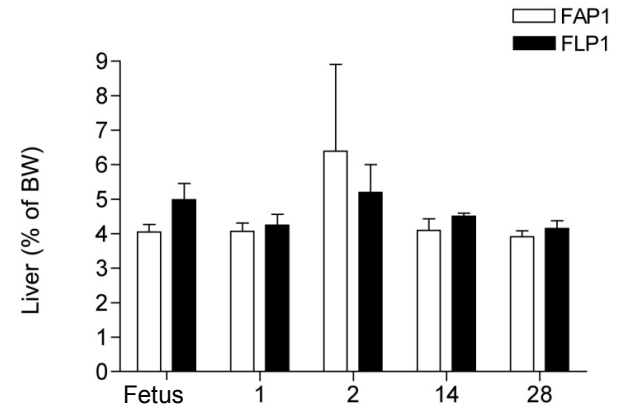

(a)

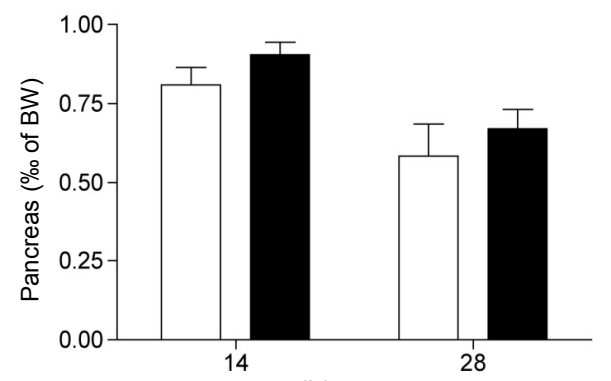

(b)

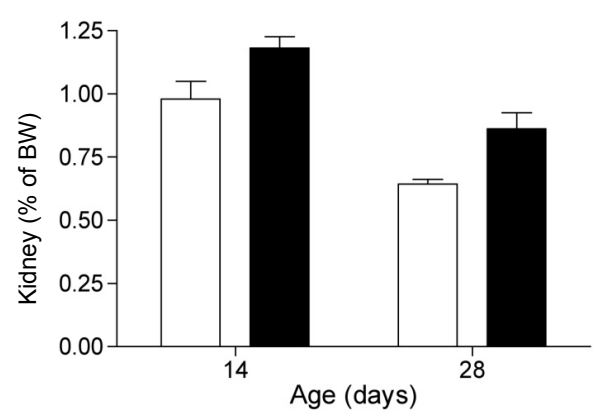

(c)

Figure 4. Mink kit organ weight in relation to body weight (\%) in mink kits exposed to an adequate (FAP1) or a low protein (FLP1) diet during late gestation. (a) Liver mass to body mass, \%; (b) Pancreas mass to body mass, \%; (c) Kidney mass to body mass, \%. Liver mass increased in proportion to body mass increase with age $(P<0.001)$, whereas pancreas and kidney mass decreased in proportion with body mass $(P<0.01$ and $P<0.001$, respectively). Body weights were: Fetus AP: $12.9 \pm 0.9 \mathrm{~g}$, LP: $8.4 \pm 1.5 \mathrm{~g} ; 1$ day old AP: $11.5 \pm 1.2 \mathrm{~g}$, LP: 10.5 $\pm 1.4 \mathrm{~g} ; 2$ days old AP: $12.5 \pm 1.0 \mathrm{~g}$, LP: $9.6 \pm$ $0.9 \mathrm{~g} ; 14$ days old AP: $100.5 \pm 4.0 \mathrm{~g}$, LP: $76.2 \pm$ 5.0 g; 28 days old AP: $257.0 \pm 17.8$ g, LP: 205.2 $\pm 16.5 \mathrm{~g}$.

out lactation in the study of Fink and coworkers [24] and throughout fetal life and suckling in the rat pup study [10]. In contrast, a shorter duration of protein restriction during the last part of gestation led to only a tendency [11] or no effect (present study) on liver mass.

Protein restriction during late gestation resulted in a lower protein oxidation as a percentage of $\mathrm{HE}$ indicating 
that the major part of dietary protein available to the dam was being utilized in protein metabolism. Although part of the requirement for fetal growth may have been provided by the mobilization of body reserves in the dam, as reflected by the negative energy retention as fat, the restricted protein supply resulted in lower nitrogen retention indicating that the dietary supply of nitrogen available for fetal growth was limited. In line with this, previous mink studies have shown a decrease in protein oxidation and nitrogen balance in late gestation during the period of exponential fetal growth when the fetal protein requirement for growth increases steeply. These previous data suggest that, even in adequately nourished dams, part of the protein requirement for fetal growth is sustained by mobilization of a labile protein reserve that has been accreted during early gestation [25]. In the case of mink dams given a low protein supply during late gestation, it can be anticipated that a relatively larger proportion of the protein demand for fetal growth is met by mobilization of body reserves.

While protein oxidation decreased, carbohydrate oxidation increased during late gestation, clearly reflecting the different nutrient content of the diets, which is consistent with findings in a similar study albeit with lower dietary protein content (14\% of ME; [11]). Indeed, a restricted protein supply during lactation resulted in a lower level of protein oxidation in lactating mink dams [26], which were able to efficiently utilize the high amounts of carbohydrate in the diet [26,27], indicating some degree of adaptability in the mink when exposed to different levels of protein supply. Whilst the duration of the dietary treatment in our study was shorter, our findings indicate that, despite a decreased availability of dietary protein, the dams had the capacity to regulate protein oxidation rate without incurring short-term adaptational changes in terms of liver mass.

\subsection{Reproductive Performance and Fetal Birth Weights}

The protein-restricted diet during late gestation resulted in higher kit losses from parturition to weaning, however, the gestational protein restriction did not change other reproductive performance aspects of the dams significantly. A diet with lower dietary protein content (14\% of $\mathrm{ME}$; [11]) resulted in $15 \%$ barrenness, $30.6 \%$ fewer kits per mated female and a lower number of live kits born per litter, thus suggesting that this protein supply was below the protein requirements for late gestation. The dietary protein content of $19 \%$ of ME used in the present study was below the lowest recommended protein supply for mink during gestation and suboptimal for practical farming conditions in the Nordic countries (36\% of ME from protein; [28]), but our diet can be seen as having had a higher content of essential amino acids and hence a better protein quality than practical farming diets. Indeed, when the effects of diets with different protein content and different amino acid composition were investigated throughout gestation and lactation, those diets with a good amino acid composition were found to support normal reproductive performance and kit growth when supplied at $26 \%$ of ME from protein [29]. Diets with a poor amino acid composition tended to cause higher kit losses in one-year old dams and poor growth in male kits until weaning while providing the same proportion of ME from protein [29]. Because our LP diet, supplied over 21 days of late gestation, caused significantly higher kit losses than our AP diet but did not affect other reproductive performance aspects significantly, we suggest that the protein supply in the LP diet was below the requirement for late gestation.

Protein restricted dams had a lower uterus weight because of lower fetus weights and litter size, which is similar to findings in rats where protein restriction during late gestation caused restricted uterine and fetal growth immediately pre-partum [30]. After mating, the mink experiences an embryonic diapause, which is variable in duration, and after implantation the length of the true gestation is $30 \pm 3$ days [13]. It is at present impossible to identify the exact gestational stage of pregnant mink dams. In this study, dams that were euthanized during pregnancy had been mated on the same dates, been exposed to the dietary treatment for an equal amount of time (14 days), and were all euthanized 43 days after the last mating. Despite this methodological consistency, one litter in the LP group was extremely light indicating late implantation compared to other litters. In contrast, one AP litter was extremely heavy indicating early implantation, and the dam was likely very close to parturition when she was euthanized. Indeed, the average weight of this litter was higher than the average for AP birth weights. With the bias of different implantation times and a difference of $30 \%$ in litter size between the two treatment groups the lower weight of uteri in LP dams cannot be ascribed entirely to a definite effect of the low protein supply. Indeed, there was no effect of protein restriction in utero when the litter that had implanted very late was exempted from the analysis. Hence, a comparative analysis of fetal parameters in the mink has to be approached with an element of caution and we conclude that the lower fetal weight in LP dams was more likely due to different implantation times than a clear effect of the dietary treatment.

The birth weights of the offspring from control dams were in agreement with previous studies $[11,14]$. The level of dietary protein restriction was sufficient to cause a significant decrease in kit birth weights. This observation is commonly accepted as an effect of intrauterine 
nutrient restriction and has previously been observed in various species (mink: [11]; mice: [31]; rats: [32]). The effect of the protein restriction in utero on kit body weights persisted until 21 days of age. These findings are supported by the study of Matthiesen and coworkers [11] who reported a tendency towards lower fetal weights, and significantly lower birth weights in the offspring of LP dams, effects that persisted until 21 days of age.

\subsection{Kit Growth}

Although body weights were lower at birth in FLP1 kits, small differences in weight gain allowed both female and male FLP1 kits to reach the same body weight as that of FAP1 kits by 21 days of age. Milk yield is affected by litter size, which is a limiting factor for mink kit growth [17]. In the present study, however, kit litter size was standardized to $6 \mathrm{kits}$, and therefore litter size had no effect on kit growth. Growth was reduced in rat offspring of protein restricted lactating mothers [10,32], while the supply of an adequate quantity of milk resulted in rapid catch-up growth in rat pups that had been protein restricted during fetal life. However, this catch-up growth was linked to increased fat mass at the expense of lean body mass and body protein content [33-35]. Lactating mink dams fed an LP diet during lactation produced milk with a lower amino acid content, but produced quantitatively more milk per kit $[26,36]$. It is at present not known how restricted protein supply during gestation affects the protein content of mink milk. However, the restricted protein supply during gestation caused mobilization of fat from dam body reserves. It can be speculated that, despite a slight positive nitrogen retention in the protein restricted dams during gestation, this pool of nitrogen might still not have been sufficient enough to support fetal growth. A previous study in pregnant dams indicated that nitrogen retained during early gestation may be mobilized during late gestation [16]. It is likely, that this mobilization of nutrients from the dam will result in suboptimal conditions for lactation performance after parturition but similar nutritional conditions to that of the intrauterine environment for the kits. Suboptimal lactation performance immediately after birth may therefore prevent the offspring from achieving a body weight similar to that of controls. Body weights were similar by 21 days of age, suggesting that the effect of the protein restriction of the dams during gestation had waned off at this time resulting in improved milk yield, thus allowing for kit catch-up growth.

The observed differences in the growth response between this study and that of Matthiesen and coworkers [11], where FLP1 kit body weight reached that of control kits by 28 days of age, might be due to the length and time of exposure to the dietary treatment in utero. According to Lucas [6] specific gestational windows exist for fetal development and hence for growth, however, due to the difficulty in predicting the time of implantation and the beginning of the true gestation in mink, it is at present not known whether and when these windows exist. In this study, the dietary treatment exposure ranged between a minimum of 13 days and a maximum of 25 days, thus covering $43 \%$ to $83 \%$ of the true gestation period, which does not differ from the study of Matthiesen and coworkers [11] covering $40 \%$ to $90 \%$. It can therefore be assumed that the same windows for growth, if any, were targeted in the two studies, and that any differences observed might be due to different levels of protein content in the restricted protein dietary treatments.

A maximal relative growth rate $\left(V_{\max }\right)$ of $18.8 \%$ occurred when kits were between 0 and 7 days old. Extrapolating the relative growth rate data by calculating a predictive exponential growth rate curve for the control kits, one arrives at a relative growth rate for day 1 of $23 \% \cdot$ day $^{-1}$, which is similar to that reported by Tauson [14]. Relative growth decreased with age, however, a lower relative growth rate was recorded in the period between 28 and 35 days than in the following two growth periods. Tauson \& Valtonen [14] argued that mink kits begin to consume solid feed in addition to milk at 3 to 4 weeks of age. Development of enzymatic activity is not complete $[37,38]$ when mink kits experience a shift in nutrient composition of the diet from high fat- $\%$ in milk to high protein- $\%$ in solid feed. The adaptation to a new nutritional environment is therefore likely to cause a temporary decrease in the relative growth rate as evidenced by the present study. Further in-depth studies of the long-term effects of the intrauterine protein restriction, fat metabolism, and endocrine mechanisms are now needed. However, the results of the current study indicate that the growth response of the LP mink kits makes them a suitable model for studies of metabolic programming.

\subsection{Organ Development}

Altered growth patterns in young individuals are linked to adaptive changes in fetal organ development in response to intrauterine environment changes [9]. In rats, protein restriction in utero caused liver and pancreas mass reduction, however, upon exposure to an adequate protein supply postnatally, liver mass was partly restored, whereas the pancreas mass was completely restored at 21 days of age [9]. In the present study, there was no effect of protein restriction during gestation on absolute organ mass or on organ mass in relation to body size in fetuses, or in kits after parturition. The liver to body weight ratio on day 2 agrees well with previous findings in mink kits [14], however, that study reported an increase from 3.5\% at birth to $5 \%$ at day 2 , which was not observed in the present study. The reason for this disparity is not known. 


\subsection{Conclusion}

Our findings suggest that the dietary protein supply was below the protein requirement for mink dams during late gestation, and that protein restriction (LP) during late gestation caused metabolic adaptations in terms of growth restriction in mink offspring $c f$ AP kits. Kit losses were higher in LP dams, however, there was no effect of a protein restricted diet on either the reproductive performance, or the quantitative metabolism of dams during lactation. Protein restriction during late gestation might have impaired lactation performance, thus delaying catchup growth. However, the restricted protein supply did not affect the organ growth of the offspring. Further investigation is now needed to establish whether late gestation protein restriction affects lactation performance in mink dams, and whether growth restriction during fetal life causes long-term metabolic changes in mink offspring resulting in altered growth patterns and organ development after weaning with the possible development of metabolically related diseases in later life.

\section{ACKNOWLEDGEMENTS}

This project was funded by Danish Agency for Science Technology and Innovation and Danish Fur Breeders Research Centre. The authors wish to thank Ebba de Neergaard Harrison, Inge Mejdahl, and Merethe Stubgaard for their valuable technical assistance with the chemical analyses, Abdalla Ali for Respiration Unit operation, and Boye Pedersen for animal handling.

\section{REFERENCES}

[1] Hales, C.N. and Barker, D.J. (2001) The thrifty phenotype hypothesis. British Medical Bulletin, 60, 5-20. doi:10.1093/bmb/60.1.5

[2] Owens, J.A., Falconer, J. and Robinson, J.S. (1989) Glucose metabolism in pregnant sheep when placental growth is restricted. American Journal of Physiology, 257, 350-357.

[3] Hales, C.N., Barker, D.J., Clark, P.M., Cox, L.J., Fall, C., Osmond, C. and Winter, P.D. (1991) Fetal and infant growth and impaired glucose tolerance at age 64. British Medical Journal, 303, 1019-1022. doi:10.1136/bmj.303.6809.1019

[4] Barker, D.J., Winter, P.D., Osmond, C., Margetts, B. and Simmonds, S.J. (1989) Weight in infancy and death from ischaemic heart disease. Lancet, 2, 577-580. doi:10.1016/S0140-6736(89)90710-1

[5] Barker, D.J., Bull, A.R., Osmond, C. and Simmonds, S.J. (1990) Fetal and placental size and risk of hypertension in adult life. British Medical Journal, 301, 259-262. doi:10.1136/bmj.301.6746.259

[6] Lucas, A. (1991) Programming by early nutrition in man. In: Bock, G.R. and Whelan, J., Eds., The Childhood Environment and Adult Disease: CIBA Foundation Symposium 156, Wiley, Chichester, 38-55.
[7] Langley-Evans, S.C., Welham, S.J. and Jackson, A.A. (1999) Fetal exposure to a maternal low protein diet impairs nephrogenesis and promotes hypertension in the rat. Life Science, 64, 965-974. doi:10.1016/S0024-3205(99)00022-3

[8] McMillen, I.C. and Robinson, J.S. (2005) Developmental origins of the metabolic syndrome: Prediction, plasticity, and programming. Physiological Reviews, 85, 571-633. doi:10.1152/physrev.00053.2003

[9] Desai, M. and Hales, C.N. (1997) Role of fetal and infant growth in programming metabolism in later life. Biological Reviews of the Cambridge Philosophical Society, 72, 329-348. doi:10.1017/S0006323196005026

[10] Desai, M., Crowther, N.J., Lucas, A. and Hales, C.N. (1996) Organ-selective growth in the offspring of protein-restricted mothers. British Journal of Nutrition, 76, 591-603. doi:10.1079/BJN19960065

[11] Matthiesen, C.F., Blache, D., Thomsen, P.D., Hansen, N.E. and Tauson, A.-H. (2010) Effect of late gestation low protein supply to mink (Mustela vison) dams on reproductive performance and metabolism of dam and offspring. Archives of Animal Nutrition, 64, 56-76. doi:10.1080/17450390903299141

[12] Tauson, A.-H. and Forsberg, M. (2002) Body-weight changes are clearly reflected in plasma concentrations of leptin in female mink (Mustela vison). British Journal of Nutrition, 87, 101-105. doi:10.1079/BJN2001500

[13] Tauson, A.-H. (1994) Postnatal development in mink kits. Acta Agriculturce Scandinavica, Section A-Animal Science, 44, 177-184.

[14] Tauson, A.-H. and Valtonen, M. (1992) Reproduction in carnivorous fur bearing animals. Jordbrugsforlaget, Copenhagen.

[15] Einarsson, E.J. (1987) Selection for litter size in mink. III. Prepartum and preweaning observations. Norwegian Journal of Agricultural Sciences, 1, 179-204.

[16] Tauson, A.-H., Fink, R., Hansen, K.B., Hansen, N.E. and Chwalibog, A. (2004) Utilization of milk energy by suckling mink kits. Archives of Animal Nutrition, 58, 181-194. doi:10.1080/00039420410001667539

[17] Fink, R., Tauson, A.-H., Hansen, K.B., Wamberg, S. and Kristensen, N.B. (2001) Energy intake and milk production in mink (Mustela vison)-Effect of litter size. Archives of Animal Nutrition, 55, 221-242.

[18] Matthiesen, C.F., Blache, D., Thomsen, P.D. and Tauson, A.-H. (2010) Feeding mink (Neovison vison) a proteinrestricted diet during pregnancy induces higher birth weight and altered hepatic gene expression in the $\mathrm{F}(2)$ offspring. British Journal of Nutrition, 104, 544-553. doi: $10.1017 / \mathrm{S} 0007114510000802$

[19] Elofson, L., Lagerkvist, G., Gustafsson, H. and Einarsson, S. (1989) Mating systems and reproduction in the mink. Acta Agriculturae Scandinavica, 39, 23-41. doi:10.1080/00015128909438496

[20] Chwalibog, A., Tauson, A.-H. and Thorbek, G. (2004) Energy metabolism and substrate oxidation in pigs during feeding, starvation and refeeding. Journal of Animal Physiology and Animal Nutrition, 88, 101-112. 
doi:10.1111/j.1439-0396.2003.00465.x

[21] Brouwer, E. (1965) Report of sub-committee on constants and factors. Eaap Publication No. 11. Academic Press, London.

[22] Chwalibog, A., Jakobsen, K., Henckel, S. and Thorbek, G. (1992) Estimation of quantitative oxidation and fat retention from carbohydrate, protein and fat in growing pigs. Journal of Animal Physiology and Animal Nutrition, 68, 123-135. doi:10.1111/j.1439-0396.1992.tb00652.x

[23] Brody, S. (1945) Bioenergetics and growth. Reinhold, New York.

[24] Fink, R., Thomsen, P.D. and Tauson, A.-H. (2007) Metabolic flexibility of lactating mink (Mustela vison) is not reflected at transcriptional level but by changes in functional liver mass. In: Ortigues-Marty, I., Miraux, N. and Brand-Williams, W., Eds., ISEP 2nd International Symposium on Energy and Protein Metabolism and Nutrition, Wageningen Academic Publishers, Wageningen, 477-478.

[25] Tauson, A.-H., Forsberg, M. and Chwalibog, A. (2004) High leptin in pregnant mink (Mustela vison) may exert anorexigenic effects: A permissive factor for rapid increase in food intake during lactation. British Journal of Nutrition, 91, 411-421. doi:10.1079/BJN20041049

[26] Fink, R., Tauson, A.-H., Chwalibog, A., Hansen, N.E., Kristensen, N.B. and Wamberg, S. (2004) Effects of substitution of dietary protein with carbohydrate on lactation performance in the mink (Mustela vison). Journal of Animal and Feed Sciences, 13, 647-664.

[27] Fink, R. and Børsting, C.F. (2002) Quantitative glucose metabolism in lactating mink (Mustela vison): Effects of dietary levels of protein, fat and carbohydrate. Acta Agriculturce Scandinavica, Section A-Animal Science, 52, 34-42.

[28] Christiansen, M.L.E., Clausen, T.N., Lassen, T.M., Sandbøl, P. and Tauson, A.-H. (2010) Essential amino acid requirements for mink throughout the life cycle. NJF Seminar, No. 440, Oslo.

[29] Skrede, A (1978) Utilization of fish and animal byproducts in mink nutrition. II. Effect of source and level of protein on female reproductive performance, and preweaning growth and mortality of the progeny. Acta Agriculturce Scandinavica, Section A-Animal Science, 28, 130-140.

[30] Stocker, C.J., Arch, J.R. and Cawthorne, M.A. (2005) Fetal origins of insulin resistance and obesity. Proceed- ings of the Nutrition Society, 64, 143-151. doi:10.1079/PNS2005417

[31] Ozanne, S.E., Lewis, R., Jennings, B.J. and Hales, C.N. (2004) Early programming of weight gain in mice prevents the induction of obesity by a highly palatable diet. Clinical Science, 106, 141-145. doi: $10.1042 / \mathrm{CS} 20030278$

[32] Pinheiro, A.R., Salvucci, I.D.M., Aguila, M.B. and Mandarim-de-Lacerda, C.A. (2008) Protein restriction during gestation and/or lactation causes adverse transgenerational effects on biometry and glucose metabolism in F1 and F2 progenies of rats. Clinical Science, 114, 381-392. doi: $10.1042 / \mathrm{CS} 20070302$

[33] Zambrano, E., Bautista, C.J., Deás, M., MartínezSamayoa, P.M., González-Zamorano, M., Ledesma, H., Morales, L., Larrea, F. and Nathanielsz, P.W. (2006) A low maternal protein diet during pregnancy and lactation has sex- and window of exposure-specific effects on offspring growth and food intake, glucose metabolism and serum leptin in the rat. Journal of Physiology, 571, 221230. doi:10.1113/jphysiol.2005.100313

[34] Desai, M., Babu, J. and Ross, M.G. (2007) Programmed metabolic syndrome: Prenatal undernutrition and postweaning overnutrition. American Journal of Physiology Regulatory Integrative and Comparative Physiology, 293, 2306-2314. doi:10.1152/ajpregu.00783.2006

[35] Desai, M., Gayle, D., Babu, J. and Ross, M.G. (2007) The timing of nutrient restriction during rat pregnancy/lactation alters metabolic syndrome phenotype. American Journal of Obstetrics and Gynecology, 196, 555.e1-555. e7.

[36] Tauson, A.-H., Fink, R., Chwalibog, A. and Rasmussen, A. (2006) Protein turnover in lactating mink (Mustela vison) is not affected by dietary protein supply. American Society for Nutrition, 136, 2061-2062.

[37] Sangild, P.T. and Elnif, J. (1996) Intestinal hydrolytic activity in young mink (Mustela vison) develops slowly postnatally and exhibits late sensitivity to glucocorticoids. Journal of Nutrition, 126, 2061-2068.

[38] Buddington, R.K., Malo, C., Sangild, P.T. and Elnif, J. (2000) Intestinal transport of monosaccharides and amino acids during postnatal development of mink. American Journal of Physiology Regulatory Integrative and Comparative Physiology, 279, 2287-2296. 